\title{
Peer-to-peer accommodation hosts: an identity framework
}

\author{
Emily P. Yeager \\ Assistant Professor of Recreation Sciences, East Carolina University
}

\section{B. Bynum Boley}

Associate Professor of Parks, Recreation, and Tourism Management within the Warnell School of Forestry and Natural Resources, University of Georgia

\section{Cari Goetcheus}

Director of the Cultural Landscape Lab and Professor of Historic Preservation, University of Georgia

\section{Meredith Welch-Devine}

Director, Interdisciplinary Programs, Graduate School and Adjunct Assistant Professor of Anthropology, University of Georgia

While peer-to-peer accommodation research is increasingly cognizant of various stakeholders impacted by the rising popularity of this disruptive phenomenon, one stakeholder remains understudied - the host. This study uses a Deductive Qualitative Analysis to explore a tripartite of peer-to-peer accommodation host identities (entrepreneurial identity, residential identity, and sustainable entrepreneur identity) within the US City of Savannah, Georgia. Peer-to-peer accommodation hosts are agents of change in the communities in which they operate. This study posits that their impacts, whether positive or negative, on communities in which they operate depend on the existence of these identities. Potential opportunities for collaboration between hosts and local municipalities are discussed in light of the proposed identity framework.

Keywords: peer-to-peer accommodations, Airbnb, hosts, Deductive Qualitative Analysis, sustainable entrepreneurship

\section{INTRODUCTION}

Research has identified a variety of stakeholders impacted by the growth of peer-topeer accommodations (for example, Airbnb, HomeAway), including the traditional accommodations sector, peer-to-peer accommodation guests and hosts, and resident non-hosts (Fang et al. 2016; Karlsson/Dolnicar 2016; Jordan/Moore 2018; Tussyadiah/Pesonen 2018; Yeager et al. 2019). One stakeholder, however, remains understudied for their perceived peer-to-peer accommodation impacts: the peer-topeer accommodation host. Previous research has restricted the host stakeholder to one identity - that of entrepreneurs (Tussyadiah 2015; Karlsson/Dolnicar 2016; Lampinen/Cheshire 2016). This study expands upon this research and uses Deductive Qualitative Analysis (Gilgun 2010) to explore a tripartite of identities of peer-to-peer accommodation hosts with both owner- and non-owner-occupied statuses within the US City of Savannah, Georgia (Figure 1). The first identity positions hosts as 


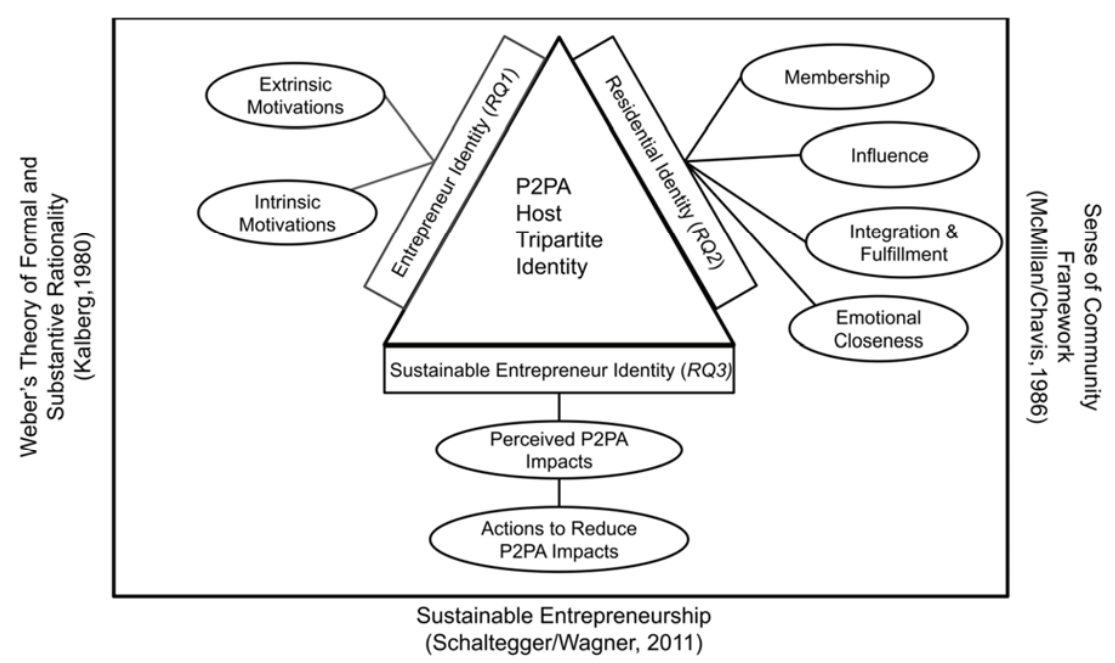

Sources: Kalberg (1980); McMillan/Chavis (1986); Schaltegger/Wagner (2011).

\section{Figure 1 The peer-to-peer accommodation (P2PA) host identity framework}

entrepreneurs in their communities, and specifically aims to understand the formal (extrinsic) and substantive (intrinsic) motivations for their participation in the peer-topeer accommodation marketplace through the lens of Weber's Theory of Formal and Substantive Rationality (Kalberg 1980).

The second identity positions hosts as residents, as evidenced by dimensions identified through McMillan and Chavis' (1986) Sense of Community framework, which includes: Membership in terms of perceived community belonging; Influence in terms of their ability to hold positions of power or authority within a community; Integration and Fulfillment of Needs in terms of perceived alignment of peer-to-peer accommodation values between hosts and resident non-hosts; and Emotional Closeness in terms of hosts' ability to share social experiences and maintain relationships with resident non-hosts. Upon integration of the entrepreneur and residential identities, hosts' perceived economic, social and environmental impacts are examined through their identity as a sustainable entrepreneur (Schaltegger/Wagner 2011). Exploration of this identity reveals how hosts struggle to balance their entrepreneurial pursuits with being good neighbors by being conscious of the positive and negative impacts of their peer-to-peer accommodations and, in some cases, attempting to create a net positive community impact through actions such as generating a significant multiplier in the local economy through guests' expenditures, intentionally increasing embeddedness in their community, and taking advantage of their ability to reduce natural resource consumption within their peer-to-peer accommodation in ways that are comparable to or that exceed traditional lodging options.

The first goal of this research is to humanize peer-to-peer hosts through an exploration of their complex motivations for hosting and their consciousness of the economic, social and environmental trade-offs associated with operating their peer-topeer accommodations. The second goal is to explore actions that hosts take to maximize the positive benefits and minimize the costs of their accommodations for the communities in which they operate. These actions exemplify the potential for 
peer-to-peer accommodations to serve as an asset to be leveraged for sustainable community development. Subsequently, municipal regulatory strategies are discussed which might further develop mutually beneficial relationships between peer-to-peer accommodation hosts and the communities in which they operate.

\section{PEER-TO-PEER ACCOMMODATION HOSTS: AN IDENTITY FRAMEWORK}

The identity of entrepreneurs has long been shaped by their image as institutional rule-breakers driven by their recognition and exploitation of market failures and a desire to better their own economic condition (Zhang et al. 2009; Elert/Henrekson 2016). Peer-to-peer accommodation hosts fit this description of entrepreneurs by their commodification of their homes to provide lodging experiences that guests might not find elsewhere in the marketplace (Pentescu 2016). However, research finds that hosts' economic motivations vary according to whether they rely upon peer-to-peer accommodation income for subsistence, such as paying off graduate school loans (Dubois 2015; Ikkala/Lampinen 2015), or to subsidize a lifestyle - for example, paying for a wedding (Dubois 2015; Hamari et al. 2015; Schor/Fitzmaurice 2015). Research also presents non-economic (intrinsic) motivations for entrepreneurial pursuits that rank high in importance for entrepreneurs - such as independence, role modeling and educating the public about the activity at hand (Carter et al. 2003; McGehee 2007; Birendra 2015). Intrinsic motivations specifically found within peer-to-peer accommodation hosts include building social connections and networks (Schor/Fitzmaurice 2015). To simultaneously explore and expand hosts' range of extrinsic and intrinsic motivations, this study draws upon Weber's Theory of Formal and Substantive Rationality (Kalberg 1980). Decisions motivated by extrinsic rewards (for example, discretionary income from peer-to-peer accommodations) are characterized as formal rationality. Conversely, decisions motivated by intrinsic rewards (for example, socialization and relationship building with guests) are characterized as substantive rationality. This theoretical approach is used within tourism literature to provide a balanced approach towards simultaneously considering formal (extrinsic) and substantive (intrinsic) motivations for entrepreneurship in agritourism (McGehee 2007). However, it has yet to be used to understand the myriad of factors influencing an individual's decision to host a peer-to-peer accommodation. With this theoretical approach in mind, the following research question was formulated:

RQ1: What is the range of formal (extrinsic) and substantive (intrinsic) benefits and costs that motivate hosts to participate in peer-to-peer accommodation activity?

The development of the entrepreneurial journey is highly contextualized by the diverse sets of socio-cultural elements existent in every community (Ulhøi 2005; Casson/Giusta 2007). Peer-to-peer accommodations' embeddedness in 'backstage' places (MacCannell 1973) - or, in other words, the residential landscape - naturally exposes and links hosts to socio-cultural elements of the communities in which they operate (for example, social norms, crime, housing values, etc.). Residential landscapes can be understood as the amalgamation of formally delineated residential areas, which, in Savannah, is accomplished through zoning of residential districts (Whitehand 1990; City of Savannah 2018b). This study proposes that hosts' capacity to consider and act upon the community impacts of their peer-to-peer accommodations hinges upon their knowledge and interconnectedness with the socio-cultural 
community elements that are linked to their accommodation. Hosts' residential identity is explored in this study using McMillan and Chavis' (1986) Sense of Community framework, which encompasses the dimensions of Membership, Influence, Integration and Fulfillment and Emotional Closeness.

The Membership dimension of the framework is defined as an individual's perceived deservingness of belonging because of their financial or social investment in a community. Relatedly, it is important to consider that individuals may hold membership in communities that are not always physically bound and can occur at many scales (Gusfield 1975; Massey 2010). Peer-to-peer accommodation hosts' activities such as remittance of occupancy and property taxes, patronage of local businesses could be considered financial investments in the community where their accommodation resides. Social investments could be characterized by activities such as promoting authentic and local culture to guests or civic engagement (for example, Neighborhood Associations). Essentially, any benefit that hosts provide to the community at large, regardless of residential status, could effectively earn them Membership or a sense of belonging to a community.

The second dimension of McMillan and Chavis' framework is Influence, which is defined as an individual's involvement in a community through positions of power or social change. Community influencers may be gatekeepers to social learning, a process comprised of activities such as conflict resolution or communication through which community members collectively generate knowledge (Armitage et al. 2009). Hosts who hold positions of Influence in the communities hosting their accommodations may be able to leverage their Membership to become community leaders in the social learning process by helping community values and norms evolve around peer-to-peer accommodations and solutions to peer-to-peer accommodation-resident conflict (Holladay/Powell 2013).

Hosts' awareness of the community's attitudes towards peer-to-peer accommodations is another product of their experience with the social learning process and can be exemplified through the third dimension of the Sense of Community framework Integration and Fulfillment. This dimension is thought to be a function of the extent to which one believes their fellow community members share the same values (McMillan/Chavis 1986). Instances of conflicting values over peer-to-peer accommodations between hosts and non-host residents may weaken relationships between these two stakeholders, thus weakening communication between neighbors. Investigation into hosts' awareness of resident non-hosts' values regarding peer-to-peer accommodations may help identify opportunities for improved stakeholder communication and collaboration.

Lastly, the strength of relationships between hosts and non-host residents can be measured by the Emotional Closeness between community members, the fourth dimension of McMillan and Chavis' Sense of Community framework. This dimension is characterized by the frequency and quality of interactions between community members. Popular media coverage of peer-to-peer accommodation impacts on community members' Emotional Closeness reveals that these impacts can be felt at the street level. Neighborhoods experiencing a significant conversion of long-term rentals to peer-to-peer accommodations in Savannah have lamented the limited opportunities for neighbor interactions and community participation (Curl 2017). In these cases, remaining residents may feel that they are living on 'ghost streets' and may harbor animosity towards peer-to-peer accommodation guests whose transience denies the Emotional Closeness they once received in their neighborhood. 
In summary, McMillan and Chavis' framework provides a tool to evaluate hosts' residential identity through their contribution to a sense of community where they operate their peer-to-peer accommodations. Depending upon the nature of a given host's residential identity, a host may actually possess the inside knowledge and motivation to serve as a facilitator of the social learning process surrounding peer-topeer accommodation values and norms. Furthermore, these hosts might be important stakeholders to include in peer-to-peer accommodation regulation processes as they are directly impacted. Their involvement in these processes might engender their buy-in into these regulations and inspire legal cooperation. With this residential identity in mind, the following research question was posed:

\section{RQ2: What is the nature of hosts' residential identity?}

Through the dual identity of peer-to-peer accommodation hosts as entrepreneurs and residents, another potential identity of hosts emerges - the sustainable entrepreneur.

This study posits that peer-to-peer accommodation entrepreneurs, who also possess some form of a residential identity, possess inside knowledge of the community impacts of peer-to-peer accommodation and that, subsequently, this awareness inspires some hosts to take actions to reduce the negative impacts and maximize the positive impacts of their peer-to-peer accommodation. These actions can be characterized as sustainable entrepreneurship, a concept rooted in both the social and institutional entrepreneurship literature. Through the lens of social entrepreneurship, social enterprises are described as those that seek equitable distribution of resources over economic gain (Ridley-Duff 2008). Institutional entrepreneurship is described as an entrepreneur's effort to contribute to changing regulatory, societal and market institutions through their business operations (Battilana et al. 2009; Schaltegger/ Wagner 2011). Through these two definitions, sustainable entrepreneurs are believed to be driven by strong environmental, economic and social values that affect all aspects of their ventures (Schaltegger/Wagner 2011).

While a growing body of research investigates the influence of peer-to-peer accommodation hosts' perceived environmental benefits on their intention to continue participation (Bellotti et al. 2015; Hamari et al. 2015), there is little knowledge about hosts' perceptions of the positive and negative impacts across the Triple Bottom Line (Elkington 2004). This study expands and adapts this line of inquiry to include the exploration of hosts' perceived environmental, economic and social benefits and costs of their peer-to-peer accommodations. With this sustainable entrepreneur identity in mind, the following research questions were developed:

RQ3: What economic, social and environmental impacts, if any, do hosts perceive that peer-to-peer accommodations have on their community?

RQ4: Do hosts take actions to reduce negative peer-to-peer accommodation impacts that would thereby qualify their identity as sustainable entrepreneurs?

\subsection{Methods}

\subsubsection{Study area}

This study takes place in Savannah, a coastal city founded in 1733 as a refuge for English debtors who would serve as the future agrarian class for the new British colony of Georgia. Because of its port, Savannah has maintained its status as a 
commercial trade center into the 21st century, expanding its portfolio of economic activity to include paper-pulp and food processing, ship building, corporate aircraft manufacturing, and now tourism (New Georgia Encyclopedia 2017).

According to the Savannah Area Chamber (2018), in 2016 the city hosted 13.7 million visitors, who spent US\$2.8 billion. The leisure and hospitality sector is currently the largest regional economic sector in Savannah, employing approximately 25,000 people; and, by December 2017, overnight visitors were generating a total of US\$20.7 million in hotel tax revenue.

As tourism has been expanding, so has the prevalence of peer-to-peer accommodations both in commercial and residential zones, leaving the city entrenched in debate over peer-to-peer accommodation regulations and management (Curl 2016; 2017). Stemming from this debate, Savannah became the first city in the state of Georgia to formally regulate peer-to-peer accommodation growth (Georgia House of Representatives 2015). These regulations were informed by a series of public stakeholder processes focused on identifying peer-to-peer accommodation issues that were negatively impacting community stakeholders, with an emphasis on the residential stakeholder. To expand upon the city's inquiry into peer-to-peer accommodation impacts, hosts were interviewed within the context of this study's proposed identity framework in order to understand their perceived positive and negative environmental, economic and socio-cultural impacts of their peer-to-peer accommodation on the community in which they operate, along with any actions that they take to reduce or maximize these impacts. Interview respondents were solicited from three districts zoned for peer-to-peer accommodations in the city: the Historic, Victorian and Mid-City Districts (Figure 2).

\subsubsection{Sample}

Hosts were recruited via peer-to-peer accommodation platforms (Airbnb, HomeAway, Vrbo and FlipKey) as well as through snowball sampling (Babbie 2013). This research attempted to identify a sample of peer-to-peer accommodation hosts proportionate to the density of peer-to-peer accommodation permits in the three districts of Savannah where such accommodation activity is permitted. At the time of sampling, there were a total of 585 registered peer-to-peer accommodations in Savannah, with 76 percent located in the Historic District, 22 percent in the Victorian District and 2 percent in the Mid-City District (City of Savannah 2017a).

\subsubsection{Interview methods}

Semi-structured interviews were conducted by the lead author; these lasted 60-90 minutes and occurred at a location and time convenient for the hosts. A total of 26 interviews were conducted, with all but one recorded digitally. Hosts were also given the option of a phone, Skype or Facebook video interview if they were not able to meet in person (Moylan et al. 2015): thus 23 interviews were conducted in person and three over the phone.

A semi-structured interview guide was generated by informal phone meetings with members of various organizations, including a peer-to-peer accommodation management company in Savannah, the Savannah Development and Renewal Authority, and Savannah's Metropolitan Planning Commission, Neighborhood Associations and Destination Marketing Organization. Additionally, interview content was generated through public stakeholder meetings regarding peer-to-peer accommodation regulations along with informal gatherings with peer-peer accommodation hosts at these 


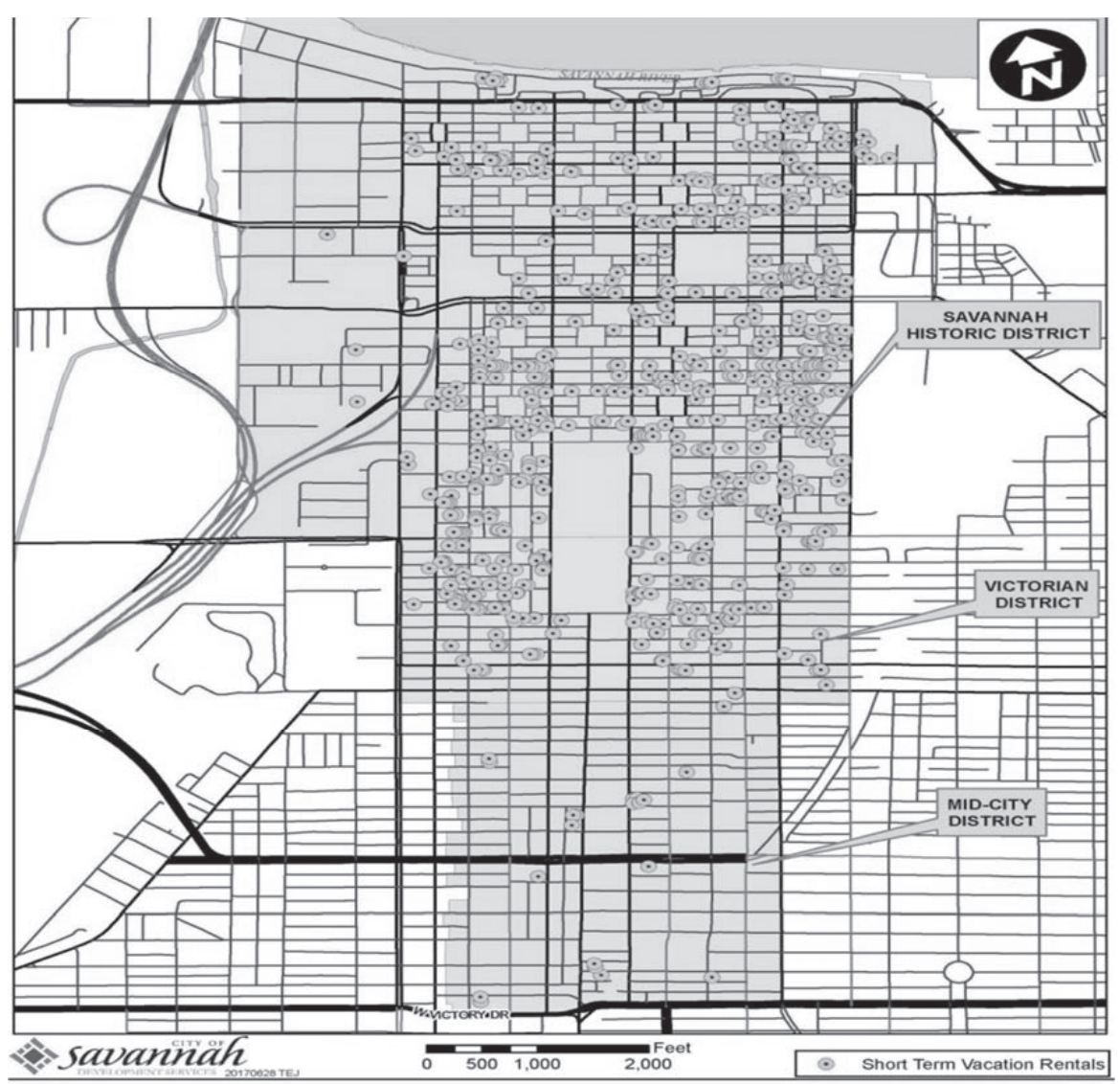

Source: City of Savannah (2017a).

\section{Figure 2 Density of peer-to-peer accommodations per district in Savannah, Georgia, zoned for peer-to-peer accommodation activity}

meetings. Before its use with research participants, the interview guide was piloted with two hosts and one resident representative of a civic organization within Savannah that did not take part in the study. The pilot testing resulted in revisions to questions related to hosts' sustainable entrepreneur identity.

Interviews were conducted with hosts until data saturation was reached, which was determined when little or no new information was gained within the realm of the study's three research angles (Rubin/Rubin 2011). Interview data were triangulated with the scope of issues addressed in peer-to-peer accommodation development stakeholder meetings as well as local media sources (Creswell 2013).

\section{ANALYSIS}

Interviews were transcribed through Express Scribe by the lead author. The qualitative data analysis software (QDAS) Atlas.ti.7 for Mac aided coding and thematic analysis 
by way of creating memos, a codebook and mapping connections between themes. Additionally, this study employs a constructivist understanding (Rubin/Rubin 2011) of hosts' perceived impacts of peer-to-peer accommodations on their community in Savannah.

Two analytical approaches were taken to explore this study's proposed identity framework. Deductive Qualitative Analysis was used to code for themes based on re-conceived identities within this study's proposed framework (Gilgun 2010; Boley/ Johnson Gaither 2016). Through Weber's Theory of Formal and Substantive Rationality (Kalberg 1980), the entrepreneurial identity was proposed to already exist within hosts. A pre-existing residential identity was thought to be held by hosts due to the inextricability of peer-to-peer accommodations in this residential landscape which would predispose hosts to hold some dimension of McMillan and Chavis' Sense of Community. The sustainable entrepreneur identity was thought to already exist among hosts who possessed both an entrepreneurial and residential identity. Grounded Theory (Corbin/Strauss 2014) was also utilized to code for themes that would enrich current conceptualizations of these identities. Additionally, Grounded Theory was employed to allow for other contextualizing factors that might emerge outside of the proposed identity framework. Member checks were completed to ensure authenticity and accuracy of the data (Creswell 2013). Reliability of the study was addressed using a 'memoing' process to document the creation of codes (Davidson/Di Gregorio 2011).

Before presenting the results of this research, it is important to offer a critical perspective of potential biases held by the lead author that may have colored the results and discussion of the data. A researcher's reflexivity in their role in this process of knowledge production increases transparency and overall trustworthiness of their research (Cohen 2013). Prior to this study, the lead author had participated in the peer-to-peer accommodation sector as a guest. Even more, Savannah was the site of their first such experience. Their positive experiences as a peer-to-peer accommodation guest indeed challenged their ability to equally consider the positive and negative impacts of peer-to-peer accommodations in Savannah. In addition to historicity, it is argued that emotions also affect the way in which researchers approach studies and interpret their findings (Burkitt 2012; Pocock 2015).

The lead author had participated in the sharing economy as an Uber driver in an attempt to better understand the entrepreneurial lifestyle of sharing economy providers. It was difficult for the lead author to ask peer-to-peer accommodation hosts to confront the potential negative impacts of their activities as it also required the author to reflect on the potential impacts that their participation as a consumer and provider in the sharing economy may have had on the communities with which they had interacted.

\section{FINDINGS}

A total of 26 interviews were conducted with 28 respondents. One interview was conducted with a couple that hosts together at a single peer-to-peer accommodation, and another was a joint interview with hosts from two separate peer-to-peer accommodations. Interviewees varied in terms of district; status of hosting versus managing peer-to-peer accommodations; owner-occupied status; residential status; average length of residency; gender; and age range (Table 1). 
Table 1 Demographics of peer-to-peer accommodation host interviewees

\begin{tabular}{|c|c|c|c|c|c|c|c|}
\hline District & $\begin{array}{c}\text { Number } \\
\text { of Inter- } \\
\text { views }\end{array}$ & $\begin{array}{l}\text { Host or } \\
\text { Manager }\end{array}$ & $\begin{array}{l}\text { Owner- } \\
\text { Occupied } \\
\text { Listing }\end{array}$ & $\begin{array}{l}\text { Live in } \\
\text { Town? }\end{array}$ & $\begin{array}{l}\text { Average } \\
\text { Length of } \\
\text { Residency } \\
\text { (years) }\end{array}$ & Gender & $\begin{array}{c}\text { Most Fre- } \\
\text { quent Age } \\
\text { Range } \\
\text { (years) }\end{array}$ \\
\hline $\begin{array}{l}\text { Histor- } \\
\text { ical }\end{array}$ & 15 & $\begin{array}{l}\text { Host: } 13 \\
\text { Manager: } 2 \\
\text { Both: } 0\end{array}$ & $\begin{array}{l}\text { Yes: } 3 \\
\text { No: } 12\end{array}$ & $\begin{array}{l}\text { Yes: } 14 \\
\text { No: } 1\end{array}$ & 7 & $\begin{array}{l}\text { F: } 10 \\
\text { M: } 5\end{array}$ & $45-64$ \\
\hline Victorian & 9 & $\begin{array}{l}\text { Host: } 8 \\
\text { Manager: } 0 \\
\text { Both: } 1\end{array}$ & $\begin{array}{l}\text { Yes: } 7 \\
\text { No: } 2\end{array}$ & $\begin{array}{l}\text { Yes: } 8 \\
\text { No: } 1\end{array}$ & 7 & $\begin{array}{l}\text { F: } 8 \\
\text { M: } 1\end{array}$ & $25-44$ \\
\hline Mid-City & 3 & $\begin{array}{l}\text { Host: } 2 \\
\text { Manager: } 0 \\
\text { Both: } 1\end{array}$ & $\begin{array}{l}\text { Yes: } 2 \\
\text { No: } 1\end{array}$ & $\begin{array}{l}\text { Yes: } 3 \\
\text { No: } 0\end{array}$ & 6 & $\begin{array}{l}\text { F: } 1 \\
\text { M: } 2\end{array}$ & $45-64$ \\
\hline No Zone & 1 & $\begin{array}{l}\text { De-registered } \\
\text { former host }\end{array}$ & Yes & Yes & 6 & F & $45-64$ \\
\hline
\end{tabular}

\subsection{Research angle 1: peer-to-peer accommodation hosts as entrepreneurs}

Hosts were motivated by a range of formal extrinsic benefits that vary according to whether they rely upon peer-to-peer accommodation income for subsistence or for subsidization of a particular lifestyle. Extrinsic subsistence motivations in this study relate to using peer-to-peer accommodation income to pay bills or expenses that cannot be deferred, including property taxes and mortgage/rent, and non-propertyrelated bills such as student loans. One host explains this possibility:

In town where rents are high, it's [peer-to-peer accommodations] probably paid half of my rent every single month, sometimes more. (T19)

Extrinsic subsidization motivations in this study relate to peer-to-peer accommodation income to pay for non-essential bills and options such as leisure travel, home renovations, supplementing retirement and saving/paying for college. One set of hosts explain that all of their peer-to-peer accommodation income is directly invested in a college fund for their young child.

We take all the money [from their Airbnb] and it just goes in an account for school. We haven't touched a dime of the money that's put in there. (T23)

Hosts were also found to be motivated by a variety of intrinsic personal benefits, including: maintaining an occupation during retirement; providing hospitality; empowerment from the ability to share one's community and home; and a sense of pride that is engendered from sharing their home and neighborhood. The most frequent intrinsic benefit cited by hosts was meeting new people. Through these encounters, some hosts have forged lasting friendships, while others have resulted in cultural exchange. The latter outcome is highlighted by one host who identifies as a black female:

I definitely have some anecdotal stories where it's [hosting] been amazing ... I had this person stay with me. She was from Denver and was staying for a wedding. She was this white woman, and we were talking about feminism and the black feminist perspective and just all these different scenarios. We got into this huge back and forth and we're sitting there with our 
unshaved armpits and it was really like ... I would never had met this woman without this passing. (T4)

Other intrinsic benefits from hosting include maintaining an occupation during retirement, guests being appreciative of the host's home, and the opportunity for hosts to share their community and home. Sometimes a host's joy in sharing their community may be tied to the enjoyment of providing hospitality as well. Approximately three-fourths of the respondents in this study offer material curating their guests' stay in the community. This ranges from brochures offered through Visit Savannah, the local destination marketing organization, to hand-drawn maps of the neighborhood with their favorite restaurants highlighted. One host couple explains how their hospitality efforts contribute to their guests' experiences:

Recently we got little seashell chocolates. We leave them in a bowl ... I letter pressed a little suggestion sheet for where to go for coffee and things to do downtown and we definitely put some real touristy information like maps in there ... I love doing that ...you really want to ask somebody who's local ... It ensures a better experience ... talking to the concierge at a hotel is different than talking to someone who lives here and works here and has family here. (T23)

In addition to sharing their community, hosts also describe a sense of pride that is engendered from sharing their home. One owner-occupied host explains how this can feel:

It's been a fun experience ... Guests are wonderful. They're appreciative. We just get such a thrill out of it. When they walk in the door, sometimes you can hear them because they haven't shut the door yet. You're down in the hallway and you can hear them like 'oh my god, oh wow' ... they are just really impressed ... we get real excited about that. (T2)

Hosts also identified intrinsic costs that may stifle their desire to host, such as the loss of a flexible lifestyle:

The only con is that we like to go camping and just drop of the grid ... Now we have to be more on the grid. We would go into rural areas and stay there for a week and literally not talk to anybody. Now you can't do that. Now I'm checking my phone for emails like ... nine times a day. (T25)

In summary, formal motivations for hosting are made complex by the fact that peer-to-peer accommodation income subsidizes some hosts' lifestyles while providing subsistence to others. Substantive motivations encompass feelings of empowerment and pride in sharing one's home and community. However, sharing these spaces appears to require sacrifices of lifestyle to accommodate guests.

\subsection{Research angle 2: peer-to-peer accommodation hosts as residents}

By proxy, hosts pursue their entrepreneurial ventures within residential neighborhoods, which embeds their accommodation within the processes and design of the residential landscape. Beyond their accommodation, hosts may opt to integrate their entrepreneurial identity with this landscape. Their decision to do so is explored through McMillan and Chavis' Sense of Community framework. Hosts' residential identity was explored using the dimensions of Membership, Influence, Emotional Closeness and Integration and Fulfillment. 
Hosts ascribe Membership to a variety of communities defined by physical boundaries, including city blocks, neighborhoods and districts. Hosts also identify with communities defined by intangible boundaries, including the peer-to-peer accommodation host community, the military community, the lesbian, gay, bisexual, transgender and questioning (LGBTQ) community, neighborhood associations and special interest groups (for example, neighborhood book clubs and social clubs). However, findings show that subscribing to the general peer-to-peer accommodation host identity may challenge cultivation of a residential identity or jeopardize acceptance in key community social groups, as described by one host:

One of the things that I learned very early on was to be quiet about was the fact that I do host ... a lot of those ladies are involved with the hospitality industry, so I said, 'Yeah I sort of am in that business on a very small scale.' I don't think I got a warm reception, so I just never said it again. And, a couple of my friends said, 'Yeah don't talk about it.' (T19)

In terms of the Sense of Community dimension Influence, hosts were asked about their outlets for leadership and general activities that would indicate their 'ownership' of their community. For some hosts, community participation takes the form of leadership in community organizations or joining community associations. Many hosts exhibited Influence through descriptions of their political activity in the context of voting and attending City Council meetings. However, some hosts have described stifled participation in the political process surrounding peer-to-peer accommodation regulations mainly because of limited Influence within the community networks chosen to inform the city's peer-to-peer accommodation regulations:

I am frustrated that the neighborhood association makes a claim that they speak for a unified voice of the neighborhood. They don't. The neighborhood association has never reached out, A) to me as a vacation rental owner or B) as a citizen. (T24)

In terms of the Sense of Community dimension Integration and Fulfillment, hosts were asked to provide perceptions of their neighbors' acceptance of peer-to-peer accommodations. This acceptance fell within a spectrum ranging from a general sense of animosity towards peer-to-peer accommodations to a general level of acceptance of peer-to-peer accommodation development in the neighborhood (Figure 3).

Beginning with the left end of the spectrum, some hosts illustrate instances of neighbors rejecting peer-to-peer accommodations in their neighborhood through complaints on social media, while other complaints may happen in person between hosts and non-hosts. Many hosts' responses fall within the 'Not Sure' point on the spectrum because their neighbors' feelings towards peer-to-peer accommodations are mixed. One respondent details an encounter with a non-hosting resident who was voicing their concerns over peer-to-peer accommodation development. This host's response to the encounter highlights the fact that a general attitude of rejection of peer-to-peer accommodations in a community does not extinguish opportunities for communication and understanding between the two stakeholders.

I met somebody just a few weeks ago who didn't realize that I was a short-term vacation rental [STVR] owner. She goes on about how short-term vacation rental owners are ruining the neighborhood. I didn't say anything. She grew up here ... And I said, 'Well full disclosure, I'm an owner.' She was a little embarrassed. I said, 'You know what? It's ok. I 


\begin{tabular}{|c|c|c|c|}
\hline District & $\begin{array}{l}\text { Historic } \\
\text { District }\end{array}$ & $\begin{array}{l}\text { Historic District, } \\
\text { Mid-City District, } \\
\text { Victorian District }\end{array}$ & $\begin{array}{l}\text { Historic District, } \\
\text { Mid-City District, } \\
\text { Victorian District }\end{array}$ \\
\hline $\begin{array}{l}\text { Spectrum of Hosts' } \\
\text { Perceived Acceptance } \\
\text { of Peer-to-Peer } \\
\text { Accommodations }\end{array}$ & $\begin{array}{l}\text { Neighbors Not Ok } \\
\text { with Peer-to-Peer } \\
\text { Accommodations }\end{array}$ & Not Sure & $\begin{array}{l}\text { Neighbors Ok } \\
\text { with Peer-to-Peer } \\
\text { Accommodations }\end{array}$ \\
\hline $\begin{array}{l}\text { Hosts' Reactions to } \\
\text { Neighbors' } \\
\text { Acceptance of } \\
\text { Peer-to-Peer } \\
\text { Accommodations }\end{array}$ & $\begin{array}{l}\text { Hosts discover } \\
\text { neighbors } \\
\text { complaining on } \\
\text { social media which } \\
\text { often angers them. }\end{array}$ & $\begin{array}{l}\text { Hosts keep their peer-to- } \\
\text { peer accommodation } \\
\text { activity quiet because of } \\
\text { peer pressure or } \\
\text { neighbors' mixed } \\
\text { feelings about peer-to- } \\
\text { peer accommodations in } \\
\text { the neighborhood. }\end{array}$ & $\begin{array}{l}\text { Hosts communicate } \\
\text { with their neighbors } \\
\text { and provide contact } \\
\text { information and } \\
\text { altruistic actions } \\
\text { such as taking their } \\
\text { trash out. }\end{array}$ \\
\hline
\end{tabular}

\section{Figure 3 Spectrum of hosts'perceptions of their neighbors'acceptance of peer-to-peer accommodations}

really wanna hear what you have to say.' It's good to know that and I get a chance to hear sort of what's going on with city council regulations. I can understand certain points for sure. (T13)

Relatedly, some hosts explained that they were not really sure what the peer-to-peer accommodation regulations were in their community, or that they feel pressure from community outcry against peer-to-peer accommodations, so they decide to keep quiet about their hosting activities to avoid any issues.

I don't know what the ordinances are in Savannah. I never asked. I don't wanna know ... I've not communicated that [hosting activity in the apartment unit] with my landlord. It's not in my lease that I can't do it. I don't want her to sneak that in. (T4)

In terms of the Emotional Closeness dimension, hosts describe examples of how relationships with their non-host neighbors are maintained as well as how they are challenged. Hosts maintain relationships with their neighbors through activities such as attending neighbors' parties, frequently seeing neighbors through daily routine (for example, walking the dog), and participation in informal neighborhood watches. One host describes the positive effect that joining their local Neighborhood Association had on their residential experience:

I went to a meeting and that's where I met this wonderful group of people and realized for the first time in meeting all of them was 'Oh my god, there are people my age that do all the same things that I do ... Like there's a million of them all around me.' It didn't make me feel alone anymore ... They became my friends, and we have parties every month ... It's now become a real community for me ... I have people who care about me. And there's people that I care about. (T2) 
In spite of these shared elements of a residential identity, media coverage in Savannah suggests that peer-to-peer accommodations challenge the Emotional Closeness between hosts and resident non-hosts (Curl 2017). Hosts seem to reflect this sentiment, particularly in regard to negative peer-to-peer accommodation posts on social media platforms (for example, NextDoor and Facebook). One host describes their reaction to a particular post on NextDoor:

That stuff that comes across that NextDoor Savannah ... somebody was making a comment on there about how they didn't like short term vacation rentals and they didn't wanna hear Mariachi music coming out of the vacation rental ... I'm not Hispanic and I don't know that I've ever had a Hispanic guest, but I'm offended by that on behalf of other hosts' cause that's just stupid ... I just said I'm out of this NextDoor Savannah. I can't be on this chatroom anymore. It used to be we're talking about our pets ... or you've got a couch for sale ... Everybody's polarized over this issue and nobody will ever listen. (T6)

In summary, hosts are much more than just entrepreneurs commodifying their homes for profit. They belong to communities with physical and intangible borders, and their decision to host significantly affects their sense of community as seen through the dimensions of Membership, Influence, Integration and Fulfillment and Emotional Closeness.

\subsection{Research angle 3: peer-to-peer accommodation hosts as sustainable entrepreneurs}

Through a coexistence of the entrepreneurial and residential identities, hosts begin to consider a range of economic, environmental and social benefits, and costs to the communities where they operate their peer-to-peer accommodations. Even more, hosts highlighted the inextricability of these impacts from each other. Additionally, hosts highlight the complexity of peer-to-peer accommodation impacts as their accommodations are not only embedded in the residential landscapes but also the overarching urban landscape. Through this multi-scalar landscape perspective, hosts contextualize the environmental, economic and social impacts by urban landscape elements, including: Housing, Resident Relocation, Tourism, Crime, Taxes, Employment, Race, Class, Walkability and Education.

Hosts recognized economic benefits of peer-to-peer accommodations related to their local tax contributions in Savannah and to the state of Georgia, as well as their ability to attract guests who in turn invest in Savannah's housing market. Hosts also associated a high multiplier effect with peer-to-peer accommodation guests because of these guests' likelihood to patronize local businesses in their quest for authentic experiences. Patronage of local businesses does not solely reside with peer-to-peer accommodation guests as hosts also describe the use of local businesses for peer-topeer accommodation maintenance and upkeep.

The consensus across all interviewees was that peer-to-peer accommodations tend to increase the value of an individual's property. Furthermore, a property's peer-topeer accommodation status could be marketed as an additional revenue stream for the owner. Home equity might also be enhanced by its convertibility into other residential assets. One host illustrated this quality through a scenario of peer-to-peer accommodation market saturation:

If the market gets saturated and people stop coming for whatever reason ... the economy goes bad ... something happens in the world like terrorism ... people stop traveling for a while. Or 
there's so many [peer-to-peer accommodations] that people can't use them all and the market goes back to empty houses ... It's gonna be much easier for people to convert those vacation rentals into long-term rentals or into homes that somebody can purchase than it is to turn hotels into some other kind of usable function. (T6)

Hosts also discussed peer-to-peer accommodations' negative economic impact on housing in terms of overall availability and affordability of long-term rentals and mortgages in Savannah:

There are no medium high-range rentals, because it is geared towards tourism. You can't come to Savannah and rent a decent property really because all the decent places make so much more doing an Airbnb or a short-term vacation property. So why would you rent it on a monthly basis? (T20)

The most frequent economic action taken by hosts was recommending local independent businesses in their neighborhood to their guests. One host from the Victorian District outlines the type of local business recommendations that they provide:

I give them a restaurant recommendation list. I send almost every one of my people to the bakery next door so that that helps that family business. I send them to the local places around them like Foxy Loxy [a locally owned coffee shop]. Places they wouldn't find by themselves ... The reason they're staying with me is that they want these local places. (T21)

Other economic actions include using local businesses for peer-to-peer accommodation maintenance and purchasing peer-to-peer accommodation supplies (for example, groceries) from locally owned stores.

Hosts perceived many positive social impacts from their accommodation. As previously highlighted, some hosts believe peer-to-peer accommodation guests are likely to search for authentic experiences, meaning that they might be more likely to include cultural and historical attractions in their trip itinerary. Hosts also discussed reduction in crime as a positive social impact of peer-to-peer accommodations:

Five years ago, when I moved in, I was afraid to walk my dog at night. Now, with the vacation rentals, people are coming home from dinner and there's people on the street [in the Victorian District]. So, this is good for my neighborhood ... I feel like I can walk by myself as a female because there's other people around. (T21)

However, hosts recognized the potential negative impacts of peer-to-peer accommodations on sense of community because of the loss of permanent neighbors:

There's this one block a couple blocks over by the park where you can see all the lockboxes [on STVR doors]. I think that it doesn't add anything positive to the neighborhood when you have full blocks that no one lives in ... Aesthetically it's a good thing I think because there's maintenance and people are definitely keeping up with the homes. But it doesn't add anything to the neighborhood ... there's no one walking their dogs. (T20)

Additionally, hosts discuss noise issues related to peer-to-peer accommodation guests. However, hosts often tied the issue of noise to peer-to-peer accommodation guests who over-indulge in the city's open container law in the Historic District, which allows individuals 21 years and older to consume alcohol beverages limited to 16 ounces within the geographic boundaries established by the Alcoholic Beverage 
Ordinance of 2015 (City of Savannah 2015). Noise issues are further contextualized by home size. Hosts explain that larger homes can accommodate larger groups who often come to Savannah to celebrate special occasions such as bachelor and bachelorette parties, which contribute to their noisiness.

In terms of social actions, hosts recommend museums and historical sites across Chatham County in order to promote a more holistic and authentic version of Savannah. Some hosts even offer personalized tours of these recommended locations. Hosts also attempt to educate guests on rules surrounding issues such as noise that could cause disruption to the community. Additionally, some hosts intentionally promote minority-owned businesses in their marketing material that they leave for guests in their peer-to-peer accommodation. One host explains this last effort:

We promote local and black-owned businesses in our binders ... So, for recommendations for things to do ... we list Day Journeys, which is a locally black-owned bus tour of Savannah. It's opposite of the carriage tour and they're really smart. It's about the Gullah Geechee and the history of African Americans in the city. (T25)

Hosts perceived positive environmental impacts of peer-to-peer accommodations that relate to natural resource consumption. One host weighed the environmental costs and benefits of peer-to-peer accommodations versus hotels:

There may not be the need for huge sky-rise hotels anymore ... and there's things like water usage. In a hotel, you're washing towels every day. There's just so much more. But in our Airbnb, we don't wash their towels every day. (T9)

In terms of negative impacts on natural resource consumption, hosts explain that peer-to-peer accommodation guests seem to use excessive amounts of products such as paper towels and toilet paper. Moreover, this excess consumption is thought to be related to guests' mindset of being on vacation.

I go through more toilet paper than you can imagine. It's insane ... I think in general, when people go on vacation, they're like oh 'yay!' and they use twice as much, which my trash has doubled, tripled. It's true. (T7)

Hosts' most frequently cited environmental action was offering recycling to guests. One host explains that, even though recycling is available, the city's current approach towards it can make accommodating the extra recycling from guests a challenge:

Once they [peer-to-peer accommodation guests] get here, they may say 'Hey, where do we put our recyclables?' I will say that is a little bit of a problem with the city because they give you these little polycarts and they service those once every two weeks instead of once every week. Sometimes, you accumulate more in that time frame. Then, that's stuff that just ends up going in the trash. (T17)

Other environmental actions included: offering composting to guests; using an energy-efficient, smart Nest thermostat; limiting the amount of laundry per stay to reduce water usage; using eco-friendly cleaning products; installing energy-efficient measures (for example, lighting, attic insulation); instructing guests to limit shower times; installing solar panels on STVRs; encouraging guests to walk everywhere; providing bike maps and information on public transportation; and providing biodegradable products for guests (for example, makeup wipes). 
In summary, hosts perceive positive and negative economic, social and environmental impacts on their community from their hosting activity that were contextualized by elements of the urban landscape. In recognition of potential impacts from peer-to-peer accommodations, hosts engage in a variety of initiatives to minimize negative impacts and maximize positive impacts of their accommodation.

\section{DISCUSSION AND CONCLUSIONS}

Rather than assigning peer-to-peer accommodation hosts a single entrepreneurial identity, as much of the previous literature has (Dubois 2015; Hamari et al. 2015; Ikkala/Lampinen 2015), this study explored a tripartite of identities that emerge from hosts being entrepreneurs whose businesses operate 'backstage' of residential communities (MacCannell 1973). The dual nature of being both entrepreneurs and residents resulted in a third identity where hosts seek to be sustainable entrepreneurs that try to maximize the positive benefits of their hosting to the community while minimizing their negative impacts (Schaltegger/Wagner 2011). These three identities have implications for municipalities trying to regulate them.

Prior research argues that the formal motivations of hosts are nuanced (Dubois 2015; Ikkala/Lampinen 2015; Hamari et al. 2015; Schor/Fitzmaurice 2015; Kalberg 1980). For example, hosts cited subsistence-related reasons for hosting (for example, paying rent), which would still fall within the realm of formal rationality for deciding to host. These findings suggest that peer-to-peer accommodation regulatory schemes should be developed in consideration of whether or not a majority of hosts' economic motivations are subsistence oriented. Therefore, if a destination like Savannah, Georgia were considering instituting a licensing scheme, fees for each license may need to be carefully considered so as not to economically discriminate against hosts who potentially rely on their peer-to-peer accommodation income for subsistence rather than subsidization of a lifestyle.

Research identifies a breadth of intrinsic motivations for hosting (Schor/ Fitzmaurice 2015). The present study contributes a new intrinsic motivation to the range of hosts' intrinsic motivations, namely the pride of sharing their homes and communities with guests. This is a bridge to their residential identities because their motivations for hosting also include showcasing the unique and special features of their neighborhood. Yeager et al. (2019) found residents' level of psychological empowerment - that is, pride in one's community (Boley et al. 2014) - from peer-to-peer accommodations in their neighborhood to be a statistically significant direct predictor of their support for the continued existence of peer-to-peer accommodations. Perhaps there is a possibility of unifying hosts and resident non-hosts who envision peer-to-peer accommodations as a tool to promote and sustain a neighborhood's character of place.

Hosts indicated belonging to communities that were physically bound (for example, neighborhoods) and those formed through values, beliefs or lifestyle (for example, military communities) (Gusfield 1975; Massey 2010). Although hosts describe a variety of financial and social investments that buy Membership into the communities where they operate, they explained that community Membership does not necessarily equate to community Influence, Integration and Fulfillment or Emotional Closeness. In fact, some hosts were alerted by other residents that they should hide their entrepreneurial host identity. This underlying tone of disapproval of hosting reflects local news stories at the time of this research that covered host and non-host 
tensions in Savannah (Curl 2017). Destinations that can leverage peer-to-peer accommodations in a visible and impactful way could potentially help ameliorate these tensions. The level of trust between hosts and non-hosts may be a significant factor in their successful collaboration in mechanisms to regulate peer-to-peer accommodation activity.

To help realize shared community visions and ameliorate tension, municipalities might consider facilitating with these two stakeholders through mechanisms such as town halls - which in fact was one method used by the City of Savannah (2017b) to further refine its peer-to-peer accommodation regulations.

However, these democratic processes should be carefully constructed. Otherwise, hosts may feel invisible and disempowered in political debates surrounding peer-topeer accommodations in their community. If this is the case, they may become uncooperative with peer-to-peer accommodation regulations set forth by a community, or decide to disinvest from a community by moving their peer-to-peer accommodation activity elsewhere. This outcome might be particularly problematic for destinations that depend upon peer-to-peer accommodation tax revenue. Hosts who contribute to a Sense of Community (McMillan/Chavis 1986) may ultimately contribute to social resilience of a community, defined as an ability to adapt to social change (Holladay/Powell 2013). This capacity for adaptation is important as peer-topeer accommodations can function as disruptive innovations within urban landscapes like Savannah that can induce sporadic and fast-paced change (Yeager et al. 2020; Davidson/Infranca 2016).

Municipalities considering the entrepreneurial and residential benefits of peer-topeer accommodation hosts in their regulatory schemes should consider another potential dimension of a host's identity, namely their official residential status. While this study finds hosts exhibiting some element of a residential identity regardless of their residential status, improving quality and frequency of interactions is arguably dependent on whether a host lives in the community where they operate their accommodation. Currently, the City of Savannah (2018a) requires owners to have a property manager within one-hour's driving distance, but no requirements for owner residential status. Municipalities that apply this identity framework and find weaknesses across the dimensions of Membership, Integration and Fulfillment and Emotional Closeness may want to compare these results to the density and locations of non-owner-occupied listings, and ultimately consider regulations that incorporate the residential status of hosts.

In some cases, the entrepreneurial and residential identities of a given host may seem to be at odds with one another. Other times, the intersecting substantive rationale to host and the residential knowledge of peer-to-peer accommodation impacts spark a sense of responsibility among hosts to immunize against the negative impacts of their listing on the communities in which they operate. Those that take action to minimize these negative impacts are the sustainable entrepreneurs. While sustainable entrepreneur hosts attempt to provide benefits to their immediate block or neighborhood, it is evident through this study that hosts in Savannah are aware that the positive and negative impacts of their peer-to-peer accommodation scale all the way to the city level. The possibility of positive city-wide impacts from peer-to-peer accommodations presents an opportunity for municipalities to leverage this viable lodging sector particularly for marketing purposes. However, to bring these larger-scale positive impacts to fruition, hosts need partnership and support from municipalities.

In terms of maximizing positive economic impacts, hosts recognized the potentially significant multiplier generated by their guests' local spending. A substantive 
motivation to share their community, enhanced through residential embeddedness, resulted in many hosts recommending local restaurants, shops and activities that guests may not have experienced otherwise if only perusing official marketing materials for Savannah. Tourism authorities within municipalities might consider meeting with peer-to-peer accommodation hosts to learn about the diverse marketing strategies that have been especially curated for their guests. Additionally, comparing city-wide official marketing materials with those of the guests may reveal new assets unbeknownst to tourism authorities, and may strengthen marketing strategies that can attract the market segment of visitors searching for authentic and localized experiences.

Hosts postulated that peer-to-peer accommodation guests' pursuit of authentic experiences would entail adding cultural and historical attractions to their trip itinerary. In similar fashion to their economic actions, hosts' substantive motivation to share the history and culture of their community was met with embedded residential knowledge of Savannah's history, which geographically spans well beyond the National Historic District (see Figure 2). Hosts curated their individualized cultural and historical landscapes of Savannah through materials on attractions (for example, museums) and personalized tours, both of which represent tourism marketing assets to be analyzed and contextualized within the broader marketing strategies of local tourism authorities. Additionally, hosts' social actions (for example, promoting local historic sites) highlight a partnership opportunity between local historical and cultural societies and sites searching for audiences to which they can market their attractions. As hosts patronize local businesses to support their entrepreneurial ventures, this seems to build their awareness of other entrepreneurs within the city, particularly those that share their broad view of the cultural landscape of Savannah. For example, one host explained their efforts to promote one particular black-owned business in Savannah which provides a counter-narrative to the city's historical carriage tour. This anecdote further hints at the possibility that hosts may produce community narratives for guests that differ slightly from those marketed within a given municipality. Rather than viewing these narratives and assets as adversarial, municipalities could view hosts' contributions as crowd-sourced authentic assets that might further refine the desired end product of a growing market segment of authentic experience seekers.

Hosts acknowledged guests' excessive consumption of resources and attributed it to a 'vacation mindset'. While many of the actions taken by hosts to reduce their accommodation's environmental footprint followed a formal rationale of cutting operating costs, the ecological benefits of their actions are still valuable. And some of the information provided to guests (such as biking maps) generate positive externalities by reducing vehicle traffic congestion and subsequent noise and air pollution for the communities in which they operate. While hosts implemented a variety of environmentally friendly initiatives (for example, recycling), they also cited barriers such as historic preservation regulations to energy-efficiency measures (for example, solar panels). Municipalities that classify peer-to-peer accommodations as residential assets would benefit from partnering with hosts who are leading the residential efforts to reduce energy consumption. Part of this partnership could include assisting hosts in finding resources (intellectual or financial) to pilot these new energy-saving measures so that baseline data might be used to persuade other homeowners to adopt successful energy-saving measures. For example, hosts within Savannah's National Historic District lamented the inability to install solar panels on their homes due to preservation ordinances that do not allow solar panels to be seen from the street. This visual limitation, combined with the thick year-round tree canopy within the district, 
prohibits many homeowners (peer-to-peer accommodation hosts or not) from pursuing this energy-saving measure for their home. In cities with similar environmental and regulatory conditions that wish to balance heritage and technological innovation, resources such as the US National Park Service's Technical Preservation Services division could be sought out and shared to explore examples of solar panel installations on historic properties (National Park Service 2018).

\subsection{Limitations}

While this study builds on the understanding of peer-to-peer accommodation hosts' multiple identities, limitations exist. First, peer-to-peer accommodation hosts' perceived levels of Integration and Fulfillment varied by district within Savannah. It is important to contextualize potential negative responses to peer-to-peer accommodations in the Historic District with other factors in the urban landscape. For example, tourism zoning and commercial activity are mostly confined within the Historic District, with mass tourism concentrated in its northwest corner - in City Market and along River Street. Residents living close to the northwest corner of the district face pre-existing pressure from tourism and likely view peer-to-peer accommodations as another contributor to this activity.

\subsection{Future research}

Future research may want to increase the number of hosts interviewed so that district-to-district comparisons can be made. Through a destination development lens, residents' attitudes towards peer-to-peer accommodations in Savannah's Historic District may be a combination of the density and type of tourism activity in proximity to their home (Doxey 1975; Butler 1980; 2004). Relatedly, this study was afforded the opportunity to interview one non-peer-to-peer accommodation zone resident who had previously hosted. This interview highlights another limitation of this study, which is that all other interviews were conducted with hosts only within peer-to-peer accommodation zones in the city. Future extension of this study could include interviews with prospective hosts in non-peer-to-peer accommodation zones to inform peer-topeer accommodation zone expansion.

One last area of future research includes exploring the experiences of underrepresented host populations. While all hosts available on peer-to-peer accommodation platforms in the city were contacted to participate in the study, only one person who identified as black female did so. Programs and organizations throughout the city reveal the entrepreneurial activity of Savannah's minority and women populations (Martin 2015; City of Savannah 2019). However, it is not clear if peer-to-peer accommodations have gained popularity or availability within the entrepreneurial portfolio of these populations (Ingham 2003).

In conclusion, this research reveals that peer-to-peer accommodation hosts are much more than just entrepreneurs commodifying their homes for profit. Through the lens of the entrepreneurial identity, hosts' formal and substantive motivations influence their decisions to host by providing a range of economic and non-economic benefits and costs that are simultaneously considered to decide whether or not the entrepreneurial activity is worth it. Even more, these economic impacts range from subsistence to subsidizing lifestyles. Hosts' possession of elements of a residential identity uniquely positions them as potentially net positive contributors to the 
communities in which they operate through utilization of intimate residential knowledge to inform their peer-to-peer accommodation operations. At the nexus of these two identities, hosts perceived environmental, economic and social impacts of their peer-to-peer accommodation; and, in many cases, engaged in activities to minimize the negative impacts from their accommodation on the communities that they operate in, thus producing one more identity - the sustainable entrepreneur.

\section{REFERENCES}

Armitage, D.R. et al. (2009): Adaptive co-management for social-ecological complexity, in: Frontiers in Ecology and the Environment, 7(2), 95-102.

Babbie, E.R. (2013): The Basics of Social Research, 6th edn, Belmont, CA: Cengage Learning.

Battilana, J., Leca, B., Boxenbaum, E. (2009): How actors change institutions: towards a theory of institutional entrepreneurship, in: Academy of Management Annals, 3(1), 65-107.

Bellotti, V. et al. (2015): A muddle of models of motivation for using peer-to-peer economy systems, in: Proceedings of the 33rd Annual ACM Conference on Human Factors in Computing Systems, 1085-1094, URL: doi:10.1145/2702123.2702272.

Birendra, K.C. (2015): Examining Networks, Social Capital, and Social Influence among Wildife Tourism Microentrepreneurs in Coastal North Carolina. Doctoral thesis, North Carolina State University, Raleigh.

Boley, B. et al. (2014): Empowerment and resident attitudes toward tourism: strengthening the theoretical foundation through a Weberian lens, in: Annals of Tourism Research, 49, 33-50.

Boley, B., Johnson Gaither, C. (2016): Exploring empowerment within the Gullah Geechee cultural heritage corridor: implications for heritage tourism development in the Lowcountry, in: Journal of Heritage Tourism, 11(2), 155-176.

Burkitt, I. (2012): Emotional reflexivity: feeling, emotion and imagination in reflexive dialogues, in: Sociology, 46(3), 458-472, URL: doi:10.1177/0038038511422587.

Butler, R.W. (1980): The concept of a tourist area cycle of evolution: implications for management of resources, in: The Canadian Geographer/Le Géographe canadien, 24(1), 5-12.

Butler, R. (2004): The tourism area life cycle in the twenty-first century, in: Lew, A.A., Hall, C.M., Williams, A.M. (eds), A Companion to Tourism, Malden, MA: Blackwell, 159-170.

Carter, N.M. et al. (2003): The career reasons of nascent entrepreneurs, in: Journal of Business Venturing, 18(1), 13-39.

Casson, M., Giusta, M. Della (2007): Entrepreneurship and social capital: analysing the impact of social networks on entrepreneurial activity from a rational action perspective, in: International Small Business Journal, 25(3), 220-244.

City of Savannah (2015): Article H: Alcoholic Beverages, URL: http://online.encodeplus.com/ regs/savannah-ga/doc-viewer.aspx $?$ secid $=1560 \&$ keywords $=$ alcoholic $\% 27 \mathrm{~s} \% 2 \mathrm{Cal}$ coholics $\%$ 2Calcoholics $\% 27 \% 2$ Calcoholic $\% 2$ Cbeverage $\% 2$ Cbeverage $\% 27 \mathrm{~s} \% 2$ Cbeverages $\% 27 \% 2 \mathrm{C}$ beverages\#secid-1560.

City of Savannah (2017a): Savannah Area Geographic Information System. URL: http:// www.sagis.org/?AspxAutoDetectCookieSupport=1.

City of Savannah (2017b): Short-Term Vacation Rentals: Managing Growth, URL: http:// savannahga.gov/DocumentCenter/View/10330/MANAGE-GROWTH-STVR-MAY-22?bidId=.

City of Savannah (2018a): Short-Term Vacation Rentals, URL: https://www.savannahga.gov/ 1476/Short-Term-Vacation-Rentals.

City of Savannah (2018b): Zoning District Information Sheets, edited by P. and U. Design, Savannah, GA, URL: https://www.savannahga.gov/1123/Zoning.

City of Savannah (2019): Savannah Business Opportunity Program, URL: https://www. savannahga.gov/374/Savannah-Business-Opportunity-Program.

Cohen, S.A. (2013): Reflections on reflexivity in leisure and tourism studies, in: Leisure Studies, 333-337, URL: doi:10.1080/02614367.2012.662522. 
Corbin, J., Strauss, A. (2014): Basics of Qualitative Research: Techniques and Procedures for Developing Grounded Theory, 4th edn, Thousand Oaks, CA: SAGE Publications.

Creswell, J.W. (2013): Research Design: Qualitative, Quantitative, and Mixed Methods Approaches, 4th edn, Thousand Oaks, CA: SAGE Publications.

Curl, E. (2016): Savannah's short term vacation rental ordinance getting another look, in: Savannah Now, URL: http://savannahnow.com/news/2016-2006-16/savannahs-short-termvacation-rental-ordinance-getting-another-look.

Curl, E. (2017): Savannah considering temporary halt on vacation rentals, in: Savannah Morning News, URL: http://www.savannahnow.com/news/2017-2006-08/savannah-consideringtemporary-halt-vacation-rentals.

Davidson, J., Di Gregorio, S. (2011): Qualitative research and technology: in the midst of a revolution, in: Denzin, N.K., Lincoln, Y.S. (eds), The SAGE Handbook of Qualitative Research, 4th edn, 627-643, Thousand Oaks, CA: SAGE Publications.

Davidson, N.M., Infranca, J.J. (2016): The sharing economy as an urban phenomenon, in: Yale Law and Policy Review, 34(2), 215-545.

Doxey, G.V. (1975): A causation theory of visitor-resident irritants: methodology and research inferences, in: The Impact of Tourism: Proceedings of the 6th Annual Conference of the Travel Research Association, 195-198, San Diego: Travel Research Association.

Dubois, E. (2015): The Field of Consumption: Contemporary Dynamics of Status, Capital, and Exchange. Doctoral thesis, Boston College Graduate School of Arts and Sciences.

Elert, N., Henrekson, M. (2016): Evasive entrepreneurship, in: Small Business Economics, 47 (1), 95-113.

Elkington, J. (2004): Enter the triple bottom line, in: Henriques, A., Richardson, J. (eds), The Triple Bottom Line, Does It All Add Up? Assessing the Sustainability of Business and CSR, London: Earthscan, 1-16.

Fang, B., Ye, Q., Law, R. (2016): Effect of sharing economy on tourism industry employment, in: Annals of Tourism Research, 57(3), 264-267.

Georgia House of Representatives (2015): Short Term Vacation Rentals Final Report, URL: https://www.house.ga.gov/Documents/CommitteeDocuments/2015/ShortTermRental_ FINAL_REPORT.pdf.

Gilgun, J.F. (2010): A primer on deductive qualitative analysis theory testing and theory development, in: Current Issues in Qualitative Research, 1(3).

Gusfield, J.R. (1975): Community: A Critical Response, New York: Harper \& Row.

Hamari, J., Sjöklint, M., Ukkonen, A. (2015): The sharing economy: why people participate in collaborative consumption, in: Journal of the Association for Information Science and Technology, 67, 2047-2059, URL: doi:10.1002/asi.23552.

Holladay, P.J., Powell, R.B. (2013): Resident perceptions of social-ecological resilience and the sustainability of community-based tourism development in the Commonwealth of Dominica, in: Journal of Sustainable Tourism, 21(8), 1188-1211.

Ikkala, T., Lampinen, A. (2015): Monetizing network hospitality: hospitality and sociability in the context of Airbnb, in: Proceedings of the 18th ACM Conference on Computer Supported Cooperative Work and Social Computing, 1033-1044, Vancouver: Association for Computing Machinery.

Ingham, J.N. (2003): Building businesses, creating communities: residential segregation and the growth of African American business in Southern cities, 1880-1915, in: Business History Review, 77(4), 639-665, URL: doi:10.2307/30041232.

Jordan, E.J., Moore, J. (2018): An in-depth exploration of residents' perceived impacts of transient vacation rentals, in: Journal of Travel \& Tourism Marketing, 35(1), 90-101.

Kalberg, S. (1980): Max Weber's types of rationality: cornerstones for the analysis of rationalization processes in history, in: American Journal of Sociology, 85(5), 1145-1179.

Karlsson, L., Dolnicar, S. (2016): Someone's been sleeping in my bed, in: Annals of Tourism Research, 58, 159-162.

Lampinen, A., Cheshire, C. (2016): Hosting via Airbnb, in: Proceedings of the 2016 CHI Conference on Human Factors in Computing Systems, 1669-1680, URL: doi:10.1145/ 2858036.2858092 . 
MacCannell, D. (1973): Staged authenticity: arrangements of social space in tourist settings, in: American Journal of Sociology, 79(3), 589-603.

Martin, K. (2015): Savannah Hispanic chamber wraps up successful first year, in: Savannah Morning News, URL: https://www.savannahnow.com/article/20151203/NEWS/312039820.

Massey, D. (2010): A global sense of place, URL: http://aughty.org/pdf/global_sense_place.pdf.

McGehee, N.G. (2007): An agritourism systems model: a Weberian perspective, in: Journal of Sustainable Tourism, 15(2), 111-124, URL: doi:10.2167/jost634.0.

McMillan, D.W., Chavis, D.M. (1986): Sense of community: a definition and theory, in: Journal of Community Psychology, 14(1), 6-23.

Moylan, C.A., Derr, A.S., Lindhorst, T. (2015): Increasingly mobile: how new technologies can enhance qualitative research, in: Qualitative Social Work, 14(1), 36-47.

National Park Service (2018): Solar Panels on Historic Properties, URL: https://www.nps.gov/ tps/sustainability/new-technology/solar-on-historic.htm.

New Georgia Encyclopedia (2017): Savannah, in: New Georgia Encyclopedia, URL: http:// www.georgiaencyclopedia.org/articles/counties-cities-neighborhoods/savannah.

Pentescu, A. (2016): Millennials, peer-to-peer accommodation and the hotel industry, in: Ovidius University Annals, Economic Sciences Series, 16(2), 262-267.

Pocock, N. (2015): Emotional entanglements in tourism research, in: Annals of Tourism Research, 53, 31-45, URL: doi:10.1016/j.annals.2015.04.005.

Ridley-Duff, R. (2008): Social enterprise as a socially rational business, in: International Journal of Entrepreneurial Behavior \& Research, 14(5), 291-312.

Rubin, H.J., Rubin, I.S. (2011): Qualitative Interviewing: The Art of Hearing Data, 3rd edn, Thousand Oaks, CA: SAGE Publications.

Savannah Area Chamber (2018): Become a member, URL: https://www.savannahchamber.com/ for-members/become-a-member.

Schaltegger, S., Wagner, M. (2011): Sustainable entrepreneurship and sustainability innovation: categories and interactions, in: Business Strategy and the Environment, 20(4), 222-237.

Schor, J.B., Fitzmaurice, C.J. (2015): 26. Collaborating and connecting: the emergence of the sharing economy, in: Reisch, L.A., Thøgersen, J. (eds), Handbook of Research on Sustainable Consumption, 410-425, Cheltenham, UK and Northampton, MA: Edward Elgar Publishing.

Tussyadiah, I.P. (2015): An exploratory study on drivers and deterrents of collaborative consumption in travel, in: Tussyadiah, I., Inversini, A. (eds), Information and Communication Technologies in Tourism, 817-830, Cham: Springer, URL: doi:10.1007/978-3-319-14343-9_ 59.

Tussyadiah, I.P., Pesonen, J. (2018): Drivers and barriers of peer-to-peer accommodation stay: an exploratory study with American and Finnish travellers, in: Current Issues in Tourism, 21(6), 703-720.

Ulhøi, J.P. (2005): The social dimensions of entrepreneurship, in: Technovation, 25(8), 939-946.

Whitehand, J.W.R. (1990): Makers of the residential landscape: conflict and change in outer London, in: Transactions of the Institute of British Geographers, 15, 87-101.

Yeager, E.P. et al. (2019): Modeling residents' attitudes toward short-term vacation rentals, in: Journal of Travel Research, 59(6), 955-974, URL: doi:10.1177/0047287519870255.

Yeager, E.P. et al. (2020): Conceptualizing peer-to-peer accommodations as disruptions in the urban toursim system, in: Journal of Sustainable Tourism, 1-16, URL: doi.10.1080/ 09669582.2020.1864387.

Zhang, Z. et al. (2009): The genetic basis of entrepreneurship: effects of gender and personality, in: Organizational Behavior and Human Decision Processes, 110(2), 93-107. 